\title{
LA VIGENCIA DE LA NOVELA DE APRENDIZAJE: UN ANÁLISIS DE CARRETERAS SECUNDARIAS, DE MÁRTÍNEZ DE PISÓN Y EL VIENTO DE LA LUNA, DE MUÑOZ MOLINA
}

\author{
Ermitas PENAS \\ Universidad de Santiago de Compostela
}

\section{RESUMEN}

El artículo pretende demostrar, tras el análisis de la estructura y el contenido de ambas novelas, que tanto la narración de Martínez de Pisón como la de Muñoz Molina pueden encuadrarse en el género del bildungsroman. Además, El viento de la Luna, por sus características específicas, es posible vincularla a una modalidad nada infrecuente en la novela de aprendizaje: la novela lírica. Los dos relatos no sólo constatan la vigencia del género mencionado, sino la impronta de la dictadura franquista que llega al lector a través de la memoria de los jóvenes protagonistas.

Palabras clave: Martínez de Pisón, Carreteras secundarias, Muñoz Molina, El viento de la luna, novela, bildungsroman, franquismo.

\begin{abstract}
By means of studying the structure and the content of these two novels, this paper tries to prove that both can fit in the genre so called bildungsroman. Besides that, the two works show the distinctive features of Franco's dictatorship, which come to the reader through the memory of their young protagonists.

Key words: Martínez de Pisón, Carreteras secundarias, Muñoz Molina, El viento de la luna, novel, bildungsroman, Franco's regime.
\end{abstract}

Resulta cuando menos curioso que prácticamente cien años después de la aparición en las letras españolas de las dos narraciones autoformativas o bildungsroma- 
ne, las emblemáticas de 1902 -Camino de perfección, de Baroja y La voluntad, de Azorín-, el siglo XX, en sus postrimerías, y el XXI, en sus comienzos, acojan dos novelas de aquella estirpe: Carreteras secundarias (1996) de Martínez de Pisón y El viento de la Luna (2006) de Muñoz Molina.

El viejo bildungsroman, cuyos orígenes pueden remontarse a la novela griega y a la medieval novela de caballerías, encuentra en nuestro Lazarillo de Tormes y después en Guzmán de Alfarache elementos fundamentales que cristalizarán en la que viene siendo considerada la obra prototípica del género de autoformación: Los años de aprendizaje de Guillermo Meister (1795-1796), de Goethe ${ }^{1}$. La pervivencia del esquema iniciático de la aventura del héroe con sus topoi característicos -el camino, el viaje, la aventura, la prueba- que constituyen su estructura antropológico-mítica, la que J. Campbell (1980:53-223) analiza en tres fases -partida, iniciación y regreso- se hace patente también en la literatura realista de las letras hispanas en la segunda mitad del siglo XIX. Ejemplos como Pepita Jiménez (1874), Pedro Sánchez (1883), Los Pazos de Ulloa (1886) y Peñas arriba (1995), alentados sobre todo por antecedentes franceses, resultan harto significativos. Pero será la novela del siglo XX, desde sus inicios, la que preste inusitada atención al género del bildungsroman. No sólo las mencionadas de la generación del 98, amén de la barojiana El árbol de la ciencia (1911), sino la larga nómina de los escritores novecentistas: la tetralogía de Ramón Pérez de Ayala, iniciada por Tinieblas en las cumbres (1907) y continuada por A. M. D. G. y La pata de la raposa, ambas de 1910, y Troteras y danzaderas (1913), Las cerezas del cementerio (1910) de Gabriel Miró, El convidado de papel (1928) y Lo rojo y lo azul (1932) de Benjamín Jarnés o El jardín de los frailes (1927) de Manuel Azaña. Seguidas por las representativas Nada (1945), de Carmen Laforet y El camino (1950), de Miguel Delibes, a quienes había precedido en versión inglesa -entre 1941 y 1946- la trilogía del exiliado Arturo Barea, La forja de un rebelde (1951). Claro que en la novela europea habían aparecido, entre otras, tres interesantes muestras del género: Las tribulaciones del estudiante Törless (1906), de Musil, Retrato de un artista adolescente (1916), de Joyce y Damián (1919), de Hesse ${ }^{2}$.

Sin ánimo de entrar en polémicas sobre la novela de aprendizaje, la llamada por Bajtín (1982) novela de educación y por Moretti (1999) novela de formación, como todo género literario, no obstante su escasa estabilidad o carácter lábil dado sus potencialidades para transformarse, mantiene unas constantes en contenido y formas literarios (Guillén, 2005:137-171). Así, su poética viene

1. Véase para la historia del género, Rodríguez Fontela (1996a).

2. La relación de títulos citados hasta el momento es simplemente indicativa, sin pretensión alguna de exhaustividad. 
definida por un conjunto de aspectos que atañen a la modalización, el tratamiento temporal y espacial, además de determinadas características temáticas ${ }^{3}$. Éstas giran en torno a la búsqueda de la identidad personal -el estado adulto-, a través de las experiencias y descubrimientos que se contraponen con la inocencia o ignorancia. Se trata de «descubrir un proceso consciente y dirigido orientándose hacia un fin determinado» (Lukacs, 1971:146). La clave está en la evolución del personaje que centra no sólo la semántica de la novela, sino los diferentes elementos estructurales. Así, en las manifestaciones del género que se inscriben en el siglo XX se subraya, más que la perspectiva de ser testigo de la historia como en las precedentes, la de la conciencia o testimonio narrativo del proceso de autoformación vivido por el protagonista, siempre partiendo del sujeto, focalizador de los hechos, que encuentra en el monólogo el cauce idóneo para representar esa conciencia. El héroe rememora su vida, en la tercera fase del regreso a los orígenes, desde la enunciación narrativa de distintos y significativos recuerdos. Y en su discurso son frecuentes las analepsis, las pausas digresivas y algunas prolepsis o anticipaciones temporales. El espacio suele cobrar una dimensión metonímica, metafórica o simbólica cuando se producen las pruebas iniciáticas. Y el final, según los distintos estudiosos, se configura abierto, normalmente en las producciones modernas, y cerrado en las novelas de aprendizaje clásicas ${ }^{4}$.

Las dos novelas de Martínez de Pisón y Muñoz Molina, con el franquismo al fondo, no obstante sus claras diferencias, gozan de evidentes similitudes que no son otra cosa que rasgos de parentesco genéricos.

Carreteras secundarias (1996) está diseñada en seis capítulos, numerados en árabe e integrados por secuencias separadas por blanco tipográfico. Narra en primera persona la autoformación de Felipe, un adolescente de catorce años, que no se lleva bien con su padre, viudo y con sucesivas parejas, médico de profesión pero dedicado a oficios marginales. Ese relato que neutraliza la oposición yoprotagonista/ yo-testigo al ser homo y autodiégetico a la vez, se vehicula a través de los diferentes cambios de residencia, y lo que ello conlleva, en un mítico viaje que va asumiendo Felipe, convertido en homo viator. La amenidad está garantizada porque de forma continua se adelantan sucesos que se aclaran más tarde provocando el constante interés del lector 5 . Pero, además, éste, como instancia

3. Fernández Vázquez (2002: 51-73) los ha sintetizado siguiendo a diferentes autores. Rodríguez Fontela (1996b: 85-174) da una rigurosa poética del género. R. Shaffner (1984: 17-18) le atribuye treinta y tres rasgos temáticos. También Salmerón (2002: 43-62) hace interesantes aportaciones.

4. Para Shaffner (1984: 27) y Rodríguez Fontela (1996a: 48 y 66-67) es abierto, para Moretti (1999:26) y Fernández Vázquez (2002:68), entre otros, es cerrado.

5. Se ha fijado en esto Sánchez Magro (1996) en su reseña. 
textual, se constituye en lector implícito. Las apelaciones que a él dirige el narrador muestran una camaradería entre ambos. Así, confía en su memoria cuando reitera lo ya mencionado o, incluso, se la aviva: «ya lo sabéis, no teníamos ni un duro» (102); «ya sabéis lo que pienso del amor» (117); «ya os he hablado de ello» (165); «Os refrescaré la memoria» (218); «¿Os acordáis?» (183) ${ }^{6}$. A veces, la voz narradora le confiesa su ignorancia sobre algo: «No me preguntéis» (105); «yo no sé» (217), o ratifica lo enunciado anteriormente: «Os lo acababa de decir» (91). En otras ocasiones le pregunta sobre sí mismo: «¿Os parezco un tipo especial? (15); ¿Os parezco un traidor o un aprovechado o algo así?» (81). Con frecuencia el narrador se dirige al lector implícito para explicar una cuestión un tanto oscura: «Pensaréis que soy un maniático» (30); «Os parecerá una tontería» (35); «Puedo pareceros que era injusto con mi padre» (177). También, identificándose con el destinatario, lo pone en conocimiento de aspectos no clarificados todavía: «¿Os preguntaréis de qué habíamos vivido hasta entonces?» (83); «¿Queréis saber por qué me hacía esas preguntas?» (150).

Todos estos ejemplos y bastantes más que podrían anotarse constituyen marcas evidentes de la comunicación, aunque no quedan desligados del rol narrativo que desempeña el protagonista. Pero, también, existen otros que adquieren trascendencia metanarrativa como señales de la fábrica del propio relato. Algunos suponen una transición: «Ahora os hablaré de mi cumpleaños» (113); «Os hablaré ahora de mi padre y su familia» (187). Otros tienen que ver con el tiempo del discurso ya que anticipan lo que se desarrollará más adelante y juegan con el suspense: «ya os hablaré de mi padre y de su famosa dignidad» (34-35); «de eso os hablaré más adelante» (101).

A pesar de esta estrecha vinculación entre el narrador y el lector implícito, éste no se convierte en narratario puesto que no llega a justificar la fenomenicidad de la escritura. Más bien su presencia textual, así como las llamadas a él dirigidas por parte del protagonista, encuentran su razón de ser en la oralidad del mensaje, enunciado por un locutor y recibido por un oyente. Esa oralidad es la que también define el estilo del texto, coherente y elaborado, de forma que la voz de Felipe se tiñe de características propias del registro coloquial.

El adolescente va contando un conjunto de aventuras y desventuras que conforman su personalidad, y siempre en inexorable atadura con la figura paterna. Relata -dice-: «mi historia con mi padre» (155). Desde el comienzo de la novela, el protagonista señala de modo tajante las divergencias con su progenitor: «éramos diferentes y nunca podríamos llegar a entendernos» (14). La rebeldía adolescente aflora en las predilecciones del muchacho: los póster de chicas ne-

6. Cito, y así lo haré en adelante, por Martínez de Pisón (1996). 
gras desnudas, echarse en el asiento de atrás del coche y sacar los pies por la ventanilla, llevar la camiseta por fuera del pantalón, blasfemar, eructar después de las comidas... También le gustan los concursos de la televisión, las tiendas de pepinillos y aceitunas, escuchar el tren con el oído pegado a los raíles, los perros o el olor de las farmacias. Sin embargo, algunas cosas que le disgustan -el deporte, las páginas de pasatiempos, la naturaleza, la gente, «ninguna de las personas que conocía» (15)- y otras que sí le atraen -la playa desierta y el sonido de las olas- demuestran las peculiaridades de Felipe. Otros objetos o facetas detestados parecen simple oposición a las preferencias de su padre: su Citroën Tiburón de segunda mano, la música de películas que pone en el coche o el actor Frank Sinatra porque «decía que se le parecía bastante» (15).

A través del relato primario, que comienza en los estertores del franquismo, exactamente en febrero de 1974 y dura un año, el muchacho toma conciencia de la transformación que ha sufrido: "yo no soy el mismo» (178), «Ya sé que este Felipe no se parece en nada al que hasta ahora conocíais» (197); «Había cambiado. No era el mismo que un año antes y lo sabía» $(244)^{7}$.

En el transcurso de este año, el adolescente, a través de diferentes etapas iniciáticas que constituyen un doble viaje -metafórico, hacia sí mismo y real, por las diferentes zonas de la geografía española en que se instala- sufre un cambio que afecta a las relaciones con su padre, inexcusable compañero de ruta. Además de la rebeldía, propia de la edad, asoman también la violencia con algún chico del colegio, ciertos comportamientos chulescos y un claro desinterés por los estudios, palpable en su absentismo del centro escolar.

El arranque del relato, en el que Antonio, el padre de Felipe, va a buscarlo a la playa para realizar un nuevo traslado, coincide con la noticia de alcance internacional, dada por la televisión, del secuestro de Patricia Hearts, rica heredera norteamericana, por el Ejército Simbiótico de Liberación. Desde ese inicio de la novela, el muchacho manifiesta una opinión negativa sobre su progenitor, a quien considera complejo, contradictorio, falso -dice lo contrario de lo que piensa- e ignorante de lo que realmente quiere. Le irritan su peculiar idea de la dignidad o su insistencia en poder vivir, al contrario que ellos y como todo el mundo, en la ciudad durante el invierno y en una urbanización costera en el verano, de aquellas que ya en esa época amenazaban el litoral mediterráneo. Felipe juzga despectivamente sus opiniones sobre los problemas de la adolescencia, sobre temas educativos y sobre el desarrollo emocional que tienen que ver con

7. Las modificaciones del protagonista son para todos los teóricos una constante en la novela de aprendizaje. Para Bajtín (1982: 212), «la transformación del propio héroe adquiere una importancia para el argumento, y en esta relación se reevalúa y se reconstruye todo el argumento de la novela». 
él, privado de la presencia de su madre. Y a todo ello se une el progresivo convencimiento por parte de Felipe de la poco ejemplar conducta paterna.

La llegada a la urbanización, cercana a El Vendrell (Tarragona), está ligada a la presencia de Estrella, aspirante a figura de zarzuela y última amante de Antonio, su agente artístico. La ruptura entre ambos, precedida por la reclamación de un dinero que él se ha gastado, provoca el enfrentamiento de Felipe con su padre. El chico se identifica, entonces, con la americana raptada que no sólo participa ahora -cinco de abril- de la misma ideología que el Ejército Simbiótico, sino que se integra en él para oponerse al magnate:

No me gustaba mi padre [...] aquella chica había sido capaz de empuñar una metralleta y lanzarse a atracar bancos sólo porque tampoco a ella le gustaba su padre [...] Yo lo ignoraba todo sobre esos señores llamados simbióticos, pero sabía que en ese momento aspiraba a ser uno de ellos. A cambiar de nombre. A agarrar un arma. A asaltar un banco sólo para protestar contra mi padre (51).

Es un modo de evidenciar el enfrentamiento del individuo con la sociedad, aquí representada por Antonio, que en muchas novelas conduce al viaje del héroe en esa primera fase de la partida. Pero esta rebelión en la que desembocan los hechos narrados en el relato primario contrasta con la sintonía, perdida después, entre padre e hijo que Felipe trae a la memoria. Mediante analepsis, algunas con un alcance de varios años, pues se sitúan en la infancia del protagonista, el chico remite a momentos en que comparte con Antonio desde el gusto por las bandas sonoras de algunas películas hasta la admiración por el doctor Barnard, del que hace un álbum de recortes y a quien llegarán a conocer en su visita a Madrid. La estancia en la capital del facultativo sudafricano, maestro en los transplantes cardíacos, fue ampliamente difundida por los medios de comunicación. Fue explotada por el régimen franquista como muestra de su interés por el mundo científico internacional que, descaradamente, se intentó capitalizar en la figura del yerno del Caudillo, Cristóbal Martínez Bordiú, autor de una bochornosa intervención quirúrgica.

Es también mediante una retrospectiva cómo el lector tiene noticias de la familia materna, de condición humilde, que vivía en Tarrasa (Barcelona), y a la que hacía seis o siete años que no veía. Otras analepsis son más próximas como en la que relata el amor de Pemartín o en las que lo hace de los diferentes empleos que Antonio va teniendo, siempre abocados al fracaso. La más antigua se refiere al negocio de los champiñones, el más lejano en el tiempo que recuerda Felipe. Sigue el de vendedor de gasolineras, con un único éxito que le permite comprar el Tiburón, cuando vivían en una urbanización de Santa Pola. Después, el de representante de Forzacao, un chocolate soluble, mientras residen en Calpe, también en la provincia alicantina. Más adelante, el de comerciante de objetos 
-tan variopintos como ropa, carritos de la compra, canarios...- provenientes de las subastas judiciales, que Antonio adquiría a bajo precio.

Una vez que se consuma la ruptura con Estrella, padre e hijo viajan a Tarrasa, donde los cuñados le entregan un dinero que aquél empleará, sin éxito, en cubrir quinielas al por mayor. El adolescente sentirá, entonces, «un inmenso desprecio» (82) hacia su progenitor al tiempo que asume su condición de eterno viajero: «marchando, siempre marchando» (91) ${ }^{8}$. El traslado a Almacellas (Lérida) supone una nueva prueba iniciática: el litoral del que tanto goza Felipe es sustituido por otro escenario del interior, simbólicamente opresivo frente a la libertad del lejano mar. Allí, y siempre con un exiguo equipaje -el aparato de televisión y unas maletas-, se instalarán en el piso de un antiguo jubilado de Renfe, que permanece igual a como él lo había dejado antes de morir. Dos objetos llamarán la atención del muchacho: un ejemplar del Quijote y un puzzle con la vista parisina del Sena y Notre Dame.

Conforme pasan los días en «aquel triste pueblo» (97), Felipe cobra conciencia de la significativa metamorfosis que ha sufrido su vida: se ha «vuelto definitivamente errática» (77). Antes «en la época de las playas de invierno y las urbanizaciones desiertas, no sabíamos hacia dónde íbamos, pero al menos sabíamos por dónde. Ahora ni siquiera eso» (97).

En Almacellas, el protagonista no va al colegio, aunque su padre lo había matriculado en uno para examinarse de fin de curso. No estudia, ve la tele, lee el Quijote y mata el tiempo como puede. Un día descubre escondidas en la parte trasera del puzzle dos cartas enviadas por su hermano al antiguo inquilino de la casa y un carné de la UGT. En ellas se hace patente la existencia de otra España: la del exilio, consecuencia de la contienda civil y subsiguiente régimen dictatorial. Su lectura le lleva a reflexionar sobre «lo sórdido que debía haber sido aquel tiempo» (101) de la inmediata posguerra, y a preguntarse «si no seguiría siéndolo entonces» (101) en ese verano de 1974, el de la famosa flebitis del Caudillo.

Es, precisamente, en ese momento histórico cuando Antonio emprende un negocio bastante lucrativo, alentado por su novia Paquita, una hippie del pueblo, al convertir el teléfono del piso en un locutorio clandestino para los temporeros del campo venidos del Sur. Estos se trasladaban, por esos años y durante los meses estivales, desde la región andaluza, con cultivos estacionales como la aceituna, para la recogida de la fruta y hortalizas, mejorando así algo sus menguadas economías.

8. Se han señalado elementos comunes entre la denominada por Bajtín (1982) novela de peregrinación o vagabundeo y la novela de aprendizaje, que no tienen por qué ser exclusivas de una u otra modalidad genérica.

Anales, 21, 2009, pp. 117-141 
El negocio paterno se continúa en otra nueva casa de Almacellas a la que deben cambiarse porque Telefónica, por falta de pago, les ha cortado el suministro, justo el día en que Felipe celebra por primera vez su cumpleaños con la consabida tarta adornada con velas.

A estas alturas del relato primario, el protagonista, a través de su experiencia de sucesivas pruebas provocadas por la conducta de Antonio -abandono de los apartamentos costeros tras vender los muebles del casero, fuga con los ahorros de sus tíos, estafa a la compañía de teléfonos...-, se percata con clarividencia de que su padre es un delincuente. Y, al mismo tiempo, advierte que en éste opera cierto tipo de cambio: ya no habla de su personal sentido de la dignidad, ni justifica sus actos.

Felipe, cada vez más lúcido a través de la progresiva maduración personal, adquiere la conciencia de que no sólo, por los continuos traslados, las diferentes casas en distintos lugares se convierten en espacios metafóricos de desarraigo que justifican su existencia como homo viator, sino que ésta ha cobrado un nuevo significado. Ya no se trata del constante marchar, sino de alejarse, escapando deprisa. Su vida es ahora «una huida» (114). Lo cual se pone de manifiesto cuando a Paquita se le ocurre hacerse con la caja registradora que contiene el dinero de la actuación de Estrella y de las consumiciones de la cafetería, creyéndolo una fortuna.

La felicidad que siente Felipe, protagonista de una aventura semejante a la de Patricia Hearts perseguida por la justicia, es sustituida por la decepción de la escasísima cuantía del botín robado y el subsiguiente abandono de Almacellas en pos de otro destino. Esta prueba iniciática conduce al adolescente a otro descubrimiento autoformativo, influido ya no por la televisión como en el caso de la heredera americana, sino por la lectura. Felipe, chico de su tiempo, que encuentra en aquélla, como sostiene M. ${ }^{a}$ T. García-Abad (2005: 105), «un referente generacional de primer orden» y convierte en «uno de los objetos fetiche de la novela», se da cuenta de que la mediática simbiótica, antes modelo de enfrentamiento con su padre, ha perdido poder de seducción. Ahora, a través de las páginas del Quijote, descubre su indisociable alianza con Antonio en un camino compartido que excluye la compañía ajena:

También nosotros recorríamos España [...] Nuestra historia era la de un largo error, una torpeza, una historia tan antigua como la de don Quijote y Sancho. Y lo único que estaba claro era que estábamos solos, como esos dos hombres. Que habíamos empezado nuestro viaje solos y que probablemente así lo terminaríamos (148).

El inmortal libro de Cervantes se convierte así en una suerte de mentor o maestro en este continuo peregrinaje, que ahora les lleva a Zaragoza. Se instalan en las afueras, al lado de la carretera de Logroño, continuando con el negocio 
del locutorio clandestino, utilizado por los americanos de la base aérea de la ciudad. Era una, junto con las de Torrejón y Morón, además de la naval de Rota, que desde 1953, por un tratado, España había conferido su mando a los Estados Unidos. Franco debió considerar una fortuna los 226 millones de dólares que le entregaron, aunque el material bélico era de la segunda guerra mundial y la de Corea. La noticia del tratado de las bases se difundió abundantemente por la radio, los periódicos y, sobre todo, el NO-DO, el noticiario propagandístico del régimen que se exhibía en las salas cinematográficas.

A través de Félix, cuya pequeña empresa de limpieza operaba en la base zaragozana, padre e hijo consiguen un pase mediante el cual Felipe recoge pelotas perdidas en el campo de golf y luego las vende en la tienda del club. El chico entra en contacto así con un mundo diferente al español de los primeros setenta: un auténtico trozo de USA en nuestro país. El muchacho se sorprende ante los militares negros y sus familias, las casas todas iguales con su jardincillo, los productos del supermercado, los imponentes coches...

En este tiempo la actitud del muchacho cambia con respecto a su progenitor: «mi antigua hostilidad [...] hacia mi padre había disminuido» (164). Ya casi no se avergüenza de él y comprende sus manías y contradicciones. Dos motivos han influido en esa diferente disposición de ánimo. Uno ha surgido como consecuencia de la nueva residencia. Se trata del amor, del que antes Felipe abominaba al verlo encarnado en la pareja de Antonio y Estrella, y ahora goza con Miranda, una chica de color de la base. El otro motivo viene de algo más atrás, cuando el muchacho aprueba el comportamiento de su padre con Paquita al dejarla regresar a Almacellas, eximiéndola de su responsabilidad en el robo de la caja fuerte.

En efecto, el enfrentamiento del protagonista con aquel, simbolizado en la rebeldía de Patricia Hearts, su heroína, desaparece así como el álbum con sus recortes. Y de repente, Felipe descubre su inequívoca afinidad con Antonio: «yo de golpe supe que inevitablemente estaba de su lado, y que mi padre podía muchas veces ser ridículo y absurdo pero era, como decirlo, era de los míos. Él y yo estábamos del mismo lado. Estábamos juntos y estábamos solos. Como Sancho y don Quijote» (165). Se trata de el momento de elección (Fernández Vázquez, 2002:67), idea clave del género (Shaffner, 1984:18) en el que el protagonista escoge, aceptando o rechazando, algo determinado en relación con su proceso formativo.

A finales de octubre o principios de noviembre, como había ocurrido en Almacellas, les cortan el teléfono y cambian de domicilio. Situado en el barrio zaragozano de Torrero, estaba no lejos de tres escenarios cargados de connotaciones negativas: la cárcel, el cementerio y el canal, que los separaba de la ciudad. Aquí parece revitalizarse la disensión de Felipe y su padre cuando éste lo envía a un 
colegio en el que se comporta de manera agresiva. Mientras, Antonio se dedica al contrabando, primero de productos imperecederos y después de electrodomésticos comprados a los americanos cuando se iban de la base. Inesperadamente, una noche despierta a su hijo y huyen. Recalan luego en un hostal de las afueras de Vitoria, la ciudad de Antonio, y allí dos policías lo detienen.

Sufre, entonces, Felipe la más dura de las pruebas de iniciación. Mientras Antonio está en la cárcel conoce a su familia, adinerada y franquista, que lo acoge en su casa, accediendo así a un mundo de comodidades y abundancia que nunca había disfrutado. Se va enterando por Ernesto y Benita, los viejos criados, del noviazgo de sus padres, de la ruptura con la abuela por un matrimonio desigual, de cómo Antonio fue expedientado, lo que le inhabilitó para ejercer su profesión de forense. Y, por todo ello, el chico lo exculpa: se ha convertido en «un perdedor» (189), fruto de unas circunstancias, habituales en aquella sociedad cerrada, que él hasta entonces ignoraba.

El protagonista es capaz de hacer un análisis de su ambivalente situación en el domicilio de su tío. Por un lado, se siente seguro en el ambiente ordenado -plan del día incluido- que se le ofrece, tan distinto al suyo, y agradecido, por lo que siempre obedece. Por otro, no ignora su posición allí como hijo de la oveja negra de la familia, depositario de la falsa caridad cristiana de sus tíos, convertida en generosa actitud. Felipe da muestras de madurez al considerar que, a pesar de que lo que le rodeaba era un lujo y sobre todo la televisión en color, «no era feliz [...] aquella vida no era mi vida» (213). Y más todavía cuando reconoce que «odiaba» (219) a esa familia porque «había sido injusta» (219) con su padre, a quien él ha elevado a la categoría de rebelde.

Durante su estancia en Vitoria, el protagonista, por primera vez, piensa mucho en Cecilia, su madre, muerta tan prematuramente, que ya no la recordaba. También va ratificando las semejanzas con su padre, de origen hereditario. Ya sabía que, como a él, no le gustaba preguntar por la situación de las calles cuando no la conocía, ni llorar, o que había buscado a Miranda como Antonio a Estrella. Ahora sabrá, porque se lo dicen, que físicamente era tan parecido a éste cuando tenía su edad, que hasta su anciana abuela los confunde. Después se dará cuenta de que, como él, tiene alma de negociante.

Esta aproximación del hijo hacia el padre cobra más cuerpo cuando el chico sufre «una auténtica revelación» (217), trascendental en su aprendizaje, al encontrar en el maletero del coche una póliza de seguros, fechada poco después de que hubiesen ido a Tarrasa. Felipe comprende, entonces, que si le tocaban las quinielas a su padre, entregaría la parte correspondiente a sus tíos, quedándose él con alguna ganancia. Si no, como había sucedido, cobraría el seguro de vida, para lo cual Antonio tendría que haber muerto. Atando cabos, el muchacho se 
da cuenta de que éste no había tenido valor para suicidarse, lo que había intentado en dos ocasiones.

Esta revelación es la que consigue que Felipe acepte la muestra de orgullo de su padre al declinar, según le ha contado el antipático padre Apellániz, director espiritual de la familia, la oferta económica del tío Jorge $e^{9}$. Es una decisión que el chico, quien cree que si Antonio «hubiese aceptado ese dinero me habría defraudado» (217), califica de «absurda, pero también heroica» (217).

Al calor de estos hechos, Felipe parece descubrir un sentimiento nuevo: el cariño hacia su padre. Mientras éste permanece en prisión, los papeles resultan sustituibles recíprocamente: «Ahora todo había cambiado. Ahora era como si yo fuera el adulto y mi padre el niño» (209). La situación se ratificará cuando Antonio sale libre: es su hijo quien lo va a buscar en un taxi, coge su maleta, da la dirección... Semeja que existe una dialéctica comparable a la sanchificación de don Quijote y a la quijotización de Sancho, de la que hablaba Salvador de Madariaga.

Realmente, la llegada forzosa a Vitoria no significa una estación más en ese periplo de padre e hijo. De esto se da cuenta Felipe, quien antes había comprendido que su vida de homo viator estaba inexorablemente ligada a Antonio: «tenía la sensación de haber llegado al final de un largo viaje y me parecía que todo eso estaba escrito en nuestro destino desde hacía mucho tiempo» (193). El chico percibe la coherencia interna de una vida dirigida a esa meta, lo que supone el regreso de su padre, en círculo cerrado, al escenario de los orígenes: «todo lo demás habían sido etapas previas que habíamos tenido que superar para llegar a ese final» (193). El sentido profundo está, además, en que la ya definitiva relación cordial entre Felipe y su padre pasa porque éste retorne al lugar de su huida y sufra ante su injusta familia y su hijo la máxima humillación, el deshonor como delincuente y presidiario. Pero también, en esa ciudad, es donde el muchacho debe conocer el auténtico pasado de Antonio.

Cuando éste recobra la libertad, regresan a Zaragoza. Antes ha vendido el Tiburón, símbolo de su falso orgullo. Felipe ha percibido la transformación de su padre: «esas semanas en la cárcel lo habían cambiado todo y ahora no cabía ya la menor posibilidad de engaño» (225). Se impone una mudanza de vida y de conducta, regidos por el estatismo y el trabajo honrado.

La existencia en Zaragoza transcurre con tristeza y precariedad. Habitan una especie de almacén, amueblado con algunos enseres que Félix les ha prestado. Antonio, que se siente «culpable y perseguido» (226) y «temeroso de la policía»

9. Puede comprobarse el peso del clero en la sociedad franquista. Aquí, aún sin nombrarla, se adivina una institución religiosa, ligada en la época a la burguesía pudiente. Los usos del colegio y los propios compañeros son contemplados por Felipe con ironía

Anales, 21, 2009, pp. 117-141 
(226), se dedica a realizar actividades de limpiador, desplazándose en una nada elegante Mobylette, y el protagonista vende a domicilio relojes Timex. La Navidad, por las dificultades, es dolorosa y melancólica.

Una mañana de invierno, un hombre y dos policías preguntan a Felipe por su padre, y éste huye atenazado por el miedo. El chico recibe la inesperada noticia de la muerte de su abuela, quien, finalmente, no ha desheredado a su hijo, mientras tanto éste pone en práctica un nuevo intento de suicidio para que el chico pueda cobrar el dinero del seguro de vida. Por una vez, y contra todo pronóstico, la fortuna triunfa sobre el destino. Antonio se restablece de sus lesiones y con su hijo parecen alcanzar una vida normal. La justicia poética se impone en el final abierto de una novela transida de humor, ironía y drama bien dosificados con evidente habilidad literaria.

El viento de la Luna (2006), que tiene idéntico diseño que Carreteras secundarias con la única diferencia del número de capítulos -aquí dieciocho-, es, también, un bildungsroman. Pero, además, como La voluntad, de Martínez Ruiz, A. M. D. G., de Pérez de Ayala, Las cerezas del cementerio, de Miró, El jardín de los frailes, de Azaña, El convidado de papel y Lo rojo y lo azul, de Jarnés o El retrato de un artista adolescente, de Joyce, puede considerarse una novela lírica, teniendo en cuenta la vinculación existente entre ambos géneros narrativos en la literatura del siglo $\mathrm{XX}^{10}$. Así, la novela de aprendizaje genera una variedad autoformativa en la que se relata autobiográficamente el proceso de maduración del protagonista, alter-ego del escritor, expresado en un lenguaje preñado de potencialidades poéticas.

En la novela lírica siguen existiendo las tres fases iniciáticas del héroe, pero se subraya sobre todo la tercera: el regreso al yo, que antes ha salido al mundo y se ha enfrentado con él, mediante el pensamiento y el recuerdo. El lector percibe ese enfrentamiento a través de un discurso fragmentario de sensaciones, emociones, sentimientos..., que se evidencia en un lenguaje poético, más que en una expresión lógica propia de esta etapa reflexiva, configurado por metáforas, alegorías, símbolos, mitos, etc., de claras virtualidades autocognoscitivas (Rodríguez Fontela, 1996a: 391-392). También, por anáforas y paralelismos sintácticos y semánticos que proporcionan un ritmo determinado a una prosa elaborada con notable cuidado.

El viento de la Luna, como Carreteras secundarias, está relatada en primera persona, aunque aquí por un innominado protagonista que también aúna o identifica en única entidad textual al narrador y al actor principal, en un tiempo retrospectivo. Va tomando conciencia de la rápida transformación de su aspecto

10. Vinculación observada por Freedman (1972), Villanueva (1983) y Gullón (1984). 
físico («Todo ha cambiado sin que yo me diera cuenta», 66) ${ }^{11}$ y de su extravío íntimo, como es característico del bildungsroman, en unos días concretos del mes de julio -16 al 21-de 1969, coincidentes con un hito de la historia espacial: la llegada del hombre al satélite sin luz. En esas fechas el adolescente de trece años y medio, pequeño experto en cuestiones aeronáuticas, sabe que el mundo seguro de la infancia se ha resquebrajado: «Hasta ahora yo había vivido sólo entre personas que de un modo u otro me eran familiares y en espacios de cálida y permanente protección que eran como extensiones de la seguridad de mi casa» (70). La soledad de entonces era compatible con el amparo:

Pasé solo los primeros años del despertar de la conciencia, solo en mis divagaciones y en la mayor parte de mis juegos pero también custodiado por los mayores y seguro de su compañía y del caudal permanente y numeroso de su ternura, tan discreta que me protegía sin sofocarme y sin volverse opresiva o debilitadora (101).

Y, sin embargo, en esos días en que el Apolo XI viaja por el espacio después de haber despegado en Cabo Kennedy, el protagonista es consciente no sólo de sus mudanzas corporales y de su soledad espiritual, sino de lo abrupto de unos cambios que desconocía: "Y ahora, de golpe, sin que yo me diera cuenta, de un día para otro, todo ha sido trastornado» (70). Siente un «desamparo íntimo que [le] acompaña a todas partes» (70), y el advenimiento del sexo con su práctica solitaria, en desconcertante mezcla de placer, culpa, vergüenza y asco, rompe también su armónico mundo infantil:

Así ha surgido alguien que va usurpando poco a poco mi vida y sin que yo me diera cuenta ha invadido mi paraíso y me ha echado, la soledad sabrosa en la que yo vivía, a la vez retirado del mundo exterior y en concordia con él. La transformación empezó a suceder sin que yo lo advirtiera (107-108).

Aflora así una conducta «de honda discordia con el mundo» (17), manifestación de la rebeldía adolescente: «Ahora siento lo que no sentí nunca [...], un encono sordo contra el mundo exterior que se resuelve en fantasías, de revancha, de coraje físico y orgullo misántropo» (71).

Ese enfrentamiento con todo y con todos, la desarmonía del héroe con la sociedad, propia del género de la novela de aprendizaje, no tiene mucha antigüedad: se remonta al curso anterior en que el personaje ingresa, disfrutando de una beca, en el Colegio Salesiano de Santo Domingo Savio, escenario de pruebas iniciáticas como también lo es para Bertuco el Colegio de la Inmaculada Concepción de los jesuitas de Regium (Gijón) en A. M. D. G. o el de los agustinos del Escorial para el innominado protagonista de El jardín de los frailes. Mientras en cursos pasados se asemejaba a sus antiguos compañeros de escuela, ahora sabe

11. Cito por Muñoz Molina (2006).

Anales, 21, 2009, pp. 117-141 
que es diferente de los actuales, pertenecientes a una clase social más elevada, a «otro mundo» que para él «no era imaginable» (68). Compañeros que no tienen que recoger aceituna en las vacaciones de Navidad, para los que no existe ni madrugar ni el trabajo manual. El nuevo colegial se siente avergonzado de su indumentaria, despreciado por los demás, amenazado por los alumnos mayores y acosado por los gamberros. En el medio hostil de la mole del edificio se encuentra «perdido» (69) porque no conoce a nadie, aislado - «separado de ellos por una barrera» (101) - y «embargado por una sensación de soledad» (172). El protagonista se ha convertido en un muchacho sin amigos que ya no conecta con los pasados de la escuela jesuítica, equiparables por la profesión paterna -tenderos, hortelanos, campesinos, vareadores- y la vecindad de la plazuela de San Lorenzo. Él es el único que ha seguido estudiando, los demás trabajan en el campo o aprenden un oficio a la par que juegan a ser hombres, fumando o acercándose a las chicas.

En el desasosegante ambiente colegial, el muchacho sufre la tortura psicológica del padre director que no sólo utiliza un «lenguaje punitivo» (154), sino que, como otros religiosos o educadores de A. M. D. G., El jardin de los frailes, Las inquietudes del joven Törless o Retrato de un artista adolescente, inflige castigos físicos. Su comportamiento, a la vieja usanza, es diferente al del padre Meter, que no amenaza con el fuego eterno ni con la condenación. Tampoco pega, aunque se mantiene indiferente a las agresiones de los demás miembros de la orden y dócilmente soporta a la superioridad ${ }^{12}$.

Además del colegio, la casa y la familia, sobre todo su padre, configuran un escenario escasamente acorde con él. Por contraste, en este caso, con el modo de vida de su tía Loli, el adolescente lector que ha cambiado a Tom Sawyer y Miguel Ostrogoff por héroes más vengativos, rebeldes y aventureros, va siendo consciente de la precariedad económica del suyo. En su mundo doméstico no existen las comodidades ni una completa higiene: no hay agua corriente, cuarto de baño, electrodomésticos, cubiertos o servilletas. Sólo es posible un retrete fuera de la vivienda, una palangana, un trapo para limpiarse las manos, la ropa remendada y rehecha, la radio, los recientes platos y la novedosa televisión. Esa falta de medios propiciada por la escasez de dinero y la acomodación familiar a lo de siempre choca con otro universo que al protagonista le está vedado -«la mayor parte de las cosas que me gustan son inaccesibles» (98)-, el de los ricos y

12. La crítica de Muñoz Molina al sistema educativo del centro se ejerce a través de la actuación de los dos religiosos. Ni la extraordinaria rigidez del Director ni la supuesta modernidad del padre Peter, del que se hace un magnífico retrato que muchos lectores tienen en su memoria, quedan bien paradas. Se huye aquí acertadamente de las sátiras extremas que, para Villanueva (1983:14), en las novelas de Pérez de Ayala y Azaña difuminan el proceso autoformativo y la personalidad del protagonista. 
extorsionadores como Baltasar o el de sus compañeros del colegio salesiano que viven en los barrios de la parte alta de la ciudad.

Además, el adolescente va asumiendo las diferencias con su familia. Son conformistas, no se rebelan ante un supuesto destino, viven en una «rutina circular» (118) y en «una perfecta indiferencia hacia el mundo exterior» (118). En esta disonancia con el entorno familiar sobresale la figura paterna, tratada con especial esmero. Es un hombre pacífico («nunca alza la voz, y nunca me ha levantado la mano, a diferencia de los padres de casi todos mis conocidos», 139), solitario, que rehúsa las agrupaciones, que impone una autoridad sin gestos («Cuando algo no le gusta, calla, y su silencio puede ser más opresivo que un grito o un puñetazo en la mesa», 139), desconfiado, callado, trabajador nato que no entiende de veraneos ni turísticos placeres estivales. Y, sobre todo, gran amante de su oficio de hortelano en su «isla del tesoro» (186), en «su paraíso» (183), cultivando los frutos «más opulentos y dulces» (181) de cada estación, después de levantarse muy temprano. El enfrentamiento con el hijo gira, precisamente, en torno a esto último, a esas labores específicas del campo que el chico va «aprendiendo sin convicción y con honda desgana» (111) mientras se siente poderosamente atraído por la lectura y los viajes espaciales de las revistas que ahora también da la televisión. No obstante, ha sido decisión paterna el enviarle al colegio religioso para que siga estudiando. Sin embargo, entre ellos no se establece un choque violento, aunque esas ocupaciones del adolescente tan lejanas del noble esfuerzo manual le preocupen o inquieten. Sólo una vez el padre pierde la calma y altera su habitual laconismo. Sucede en la cena que se narra en el capítulo octavo, de claras reminiscencias teatrales e incluso costumbristas. El diálogo familiar y los movimientos impiden ver y oír al protagonista las noticias televisivas sobre el Apolo XI. El padre maldice haber hecho caso a su cuñada comprando en la tienda de su marido el electrodoméstico, lo apaga y anuncia el fin de la holganza vacacional. Mientras el adolescente, gran conocedor del tema, explica mediante una sandía y unas cuantas frutas el sistema solar a toda la familia, su progenitor expresa su desconfianza ante los avances aeronáuticos de los americanos, que considera falsos. A lo que añade una interrogación dirigida al chico sobre cómo va a ganarse la vida si no aprende a trabajar en el campo y se dedica a leer y seguir los viajes espaciales. El anticlímax lo pone el abuelo, que con su sempiterna cachaza comenta que se ha enterado de todo lo que ha dicho su nieto, pero expresa la duda de cómo entrar en la Luna cuando los astronautas lleguen a ella.

Entre padre e hijo se produce más bien un proceso de recíproco distanciamiento, tan habitual en la adolescencia: antes hablaban mucho pero ahora «parece que cada uno de los dos se ha replegado a su oquedad de silencio, él 
alimentando su queja por mi haraganería y mi despego hacia mi campo, yo mi disgusto hacia las órdenes que he de obedecer» (139). Cuando era un niño le gustaba ir a la huerta con él y ayudarle era un juego que les permitía estar juntos. Ahora son dos extraños el uno para el otro: el padre se siente «incómodo ante este desconocido de mirada huidiza que ha suplantado el lugar de su hijo» (113) y éste «de pronto» no tiene «nada que decirle, porque también está del otro lado de la barrera invisible que se ha levantado entre el mundo exterior y yo, hecha de lejanía, de extrañeza y de vergüenza» (139).

Frente a ese mundo exterior, el amenazante del colegio y el singular de su casa, el protagonista se encastilla en el espacio imaginario de la lectura y en el físico de su aislado dormitorio, en el piso más alto: «Sólo me siento seguro en el refugio quimérico de los libros, sólo experimento una sensación plena de cobijo si me recluyo en mi cuarto al que casi no llegan los ruidos y las voces de la casa» (72). La lectura no es únicamente escondite amparador: «Cada libro es la última cámara sucesiva, la más segura y honda» (166), también supone evasión: «Un libro es una madriguera para no ser visto y una isla desierta en la que encontrarse a salvo y también un vehículo de huida» (166). El paso del proceso lector al imaginativo resulta automático: «Empiezo a leer y ya estoy sumergiéndome» (167). La lectura, que aúna la flagrante paradoja de lo cerrado y lo abierto, permite mantenerse al margen del mundo cotidiano, carente de atractivas posibilidades:

Quién puede conformarse con la seca y pobre textura de la realidad inmediata, de las obligaciones y sus mezquinas recompensas, con la explicación teológica, sombría y punitiva del mundo que ofrecen los curas en el colegio o con la expectativa del trabajo en la tierra al que mis mayores han sacrificado sus vidas y en el que esperan que yo también me deje sepultar (166-167).

En esos días de julio, que centran el relato primario de la novela, se produce una sugestiva y metafórica identidad entre el protagonista y el tripulante del Apolo XI: «Con los ojos cerrados me imagino que soy ese astronauta» (10). Esa identificación entre ambos se origina porque la soledad ante lo desconocido, el agradable y seguro aislamiento del mundo exterior, y la libertad de la aventura son parejos: «me imagino protegido de todo en el interior de un traje espacial, flotando en una cápsula que viaja hacia la Luna» (72). También se asemeja la liviandad en el refugio aeronáutico y en el refugio del lecho: «Mientras los astronautas duermen en sus sillones anatómicos, atados a ellos para que la falta de gravedad no les haga flotar en el aire [...] Casi floto en una gustosa ingravidez sobre mi cama» (136).

Simultáneamente al periplo espacial, símbolo también del camino al interior de la conciencia adolescente, el muchacho no sólo se aísla en los libros, sino en «las noticias sobre el viaje del Apolo XI» (163) y aguarda «con impaciencia los 
boletines horarios de la radio y los telediarios en los que se ven imágenes borrosas de los astronautas flotando en el interior de la nave» (163). Nada extraño en un ser que lee novelas del espacio, manuales de astronomía, zoología y botánica, y se sabe de memoria, como el Viaje al centro de la Tierra, de Julio Verne, datos de las enciclopedias sobre los cuerpos celestes. En estos fondos de la biblioteca pública toma contacto con personajes que, como él, «quieren descubrir el mundo y a la vez huir de la compañía de los seres humanos» (163). Sin embargo, en esos días de julio descubre que sus autores «pierden el resplandor de la anticipación y se vuelven (...) anacrónicos» (164) porque sus arriesgadas y extrañas relaciones son «menos novelescas que las que da la realidad» (164), las que trasmite la radio y la televisión.

Además, en El viento de la Luna, la lectura y la odisea espacial no sólo sirven para que el protagonista descubra que su existencia ha de ser distinta a la planificada por su padre, sino que a su través se inicia la partida en ese viaje simbólico más que real ${ }^{13}$.

También el cine, como la literatura de ciencia ficción, pero superándola por el poder de la imagen, es otra posibilidad de evasivo ensueño: cuando sus luces «se apagaban uno se disponía a una forma de inmersión más poderosa que la de la lectura» (177). Pero cine y literatura son, asimismo, vehículo de satisfacción sexual al que le conducen determinados pasajes de El mono desnudo o escenas de películas protagonizadas por atractivas actrices. Al viejo hábito de la lectura se ha unido, desde hace un año, el onanismo. Ambos, sus «dos placeres más secretos» (169), «sus dos vicios solitarios» (169), llegan a actuar en reciprocidad: le dejan «igual de enajenado, y muchas veces se alimentan entre sí» (169). Y los dos necesitan del ocultamiento -en la habitación del último piso de la casa o en el retrete- porque, piensa, el protagonista, «tengo que huir y tengo que esconderme» (169), recluido en la soledad «como un astronauta en su cápsula» (106).

En la novela lírica de aprendizaje, tal es El viento de la Luna, el tratamiento temporal cobra gran relevancia al fundirse la marcada temporalidad del género novelístico y la atemporalidad del género lírico (Villanueva, 1983: 19-20; Gu1lón, 1984: 55 y ss.). Ese antitético encuentro produce determinadas consecuencias: la ruptura de la linealidad temporal, el predominio de la retrospección, el sometimiento del tiempo físico - pasado, presente y futuro- al presente narrativo del que revive o rememora, la congelación estática de vivencias y recuerdos, y la ucronía (Rodríguez Fontela, 1996b: 69). Pues bien, el protagonista de la no-

13. Villegas (1973:15) considera que ese alejamiento del mundo cotidiano no tiene porque tener exclusivamente una existencia verdadera. Sin embargo, al final de la novela se insinúa que también se produjo un viaje de hecho.

Anales, 21, 2009, pp. 117-141 
vela de Muñoz Molina quiebra la linealidad narrativa de esos días del verano de 1969, coincidentes con el viaje espacial del Apolo XI, con numerosas analepsis que, como hemos dicho, suelen tener un alcance de unos meses atrás, los que se refieren al curso académico pasado cuando ingresa en el nuevo y acosador centro educativo. Pero también hay otras más remotas, que llegan a la época infantil, como las que se centran en la fiesta de los Reyes Magos, en la única vez que fue al cine solo con su padre a ver Los hermanos Max en el Oeste, en cuando jugaba en el huerto y se convertía en héroe aventurero, en el noviazgo de su tía Loli, etc.

Tanto las retrospectivas que aluden al curso 1968-1969 como las menos próximas se suscitan por el camino de la asociación siguiendo los viejos parámetros proustianos. Son con frecuencia reiterativas y, claro está, obedecen a la memoria selectiva del protagonista. Esto viene impuesto por las exigencias de la autoformación: en el aprendizaje interesa lo que el yo narrador considera fundamental para el aprendizaje. Por tanto, como el género dicta, no se trata de construir una historia rica en incidentes, sino de sustituir los materiales episódicos tanto por recuerdos trascendentales como por digresiones -aquí numerosas sobre el tema espacial, presente en todos los capítulos-, que confieren a El viento de la Luna, novela lírica, un marcado carácter intelectual o reflexivo (Villanueva, 1983: 15).

Los principales motivos que surgen en estas analepsis presentan al adolescente como protagonista de pruebas iniciáticas, como se indicó antes. Son enfrentamientos con el entorno colegial y familiar, pero también consigo mismo ${ }^{14}$. En este sentido cobra especial relevancia el descubrimiento del sexo y el sentido de culpa, subrayado por los frailes, sobre todo por el director en los ejercicios espirituales, como en otras novelas del género. No obstante, el padre Peter con sus métodos más actuales -prefiere la conversación al confesionario, cultiva la sonrisa y el trato amistoso- ofrece no sólo otro enfoque de la religiosidad -la oración como charla con Dios, la eucaristía como encuentro, la comunión como acto compartido-, sino del onanismo. Para el profesor de Geografía Universal, que pone diapositivas en clase y presta al adolescente libros del jesuita Martín Vigil, el vicio solitario tan sólo es acción egoísta, pero no camino seguro hacia la ruina corporal, por las enfermedades que contrae, y hacia la condenación eterna. Y el muchacho lo interroga sobre problemas cuya solución no es fácil de compatibilizar con la creencia en la providencia divina -el sufrimiento de los

14. No obstante, las prolepsis anticipan la armonía con la figura paterna. Cuando un amigo le asegura a ésta que la lectura y la afición a los viajes a la Luna son una anormalidad viciosa, la intervención del padre es considerada así desde la madurez del hijo: «hubiera debido darme cuenta de que en la voz de mi padre había un fondo de ternura y lealtad hacia mí» (115). También, la evocación de sus manos ásperas: «Debería uno conservar el recuerdo de la última vez que caminó de la mano de su padre» (113). 
seres inocentes, el dolor en el mundo- o con la lectura del Génesis a la luz del evolucionismo darwiniano. Muestra así, una vez más, su rebeldía: «me siento audaz haciendo estas preguntas, casi malvado, casi un hereje» (144).

Pero en determinados momentos de estas jornadas estivales del viaje espacial, el protagonista accede a revelaciones o epifanías que disipan las ambigüedades o dudas narradas en las analepsis. En el capítulo décimo recuerda cómo unos meses antes dejó de cumplir el precepto dominical una tarde de especial rebelión: «sentía una mezcla rara de vergüenza de mí mismo y de discordia hacia el mundo, de encono contra Dios omnipotente y contra sus representantes en la Tierra, los curas pálidos y crueles a cuya autoridad me vería sometido de nuevo en cuanto llegara la mañana siniestra del lunes (172-73). La falta de respuesta por parte del padre Peter a sus audaces preguntas, la práctica rutinaria de los sacramentos y la «hostilidad y desagrado físico» (173) que le producían las gentes que acuden a la iglesia, le llevan a tomar una decisión, aún consciente de cometer un pecado: «nunca más iría a misa a no ser que me obligaran» (175).

Pues bien, el jueves, 17 de julio de mañana, el adolescente regresa al colegio para entrevistarse con el salesiano y devolverle unos libros, lo que se narra en el capítulo noveno. Es una visita que no apetece por «el aburrimiento anticipado de la conversación» (146), pero que utiliza como excusa para no trabajar con su padre. Ese tipo de lecturas «hasta hace poco [le] despertaban emociones religiosas, [le] aliviaban la angustia y la culpabilidad, incluso [le] inculcaban como una vaga inquietud de hacer[se] misionero, de dar[se] a los demás sin esperar la compensación de [su] egoísmo» (146).

Sin embargo, ahora le parecen «palabrería teológica y sentimentalismo cristiano» (145) y por eso no los ha leído, aunque miente afirmando lo contrario. Continúa haciendo inteligentes preguntas de sublevado -«Yo mismo me asombro de mi impertinencia» (157)-, llenas de hostilidad y dictadas por el deseo de terminar la incómoda charla y abandonar el despacho. No obtiene una respuesta convincente y se declara agnóstico (162). El padre Peter, que sabe que su alumno no ha cumplido la promesa de atender la llamada vocacional, dice mostrarse comprensivo con las inquietudes del muchacho y, en un plan más íntimo y de cercanía física, le propone confesión. No lo acepta el protagonista que, mintiendo de nuevo con el pretexto de la ayuda a su padre, huye del aparente e interesado amparo del cura y de unas creencias que para él, por acríticas, ya no lo son. Es un momento de elección, como el anterior de prescindir de la misa dominical, marcado por el rechazo a la religión y sus formas, tan presente en la sociedad de aquellos años.

Este encuentro con el padre Peter es precedido, en el tiempo de la historia del relato primario, por la noche del 16 y madrugada del 17 de julio cuando el 
chico es vencido por el sueño: «Yo me había dormido muy tarde, escuchando en la radio la última crónica del corresponsal desde Cabo Kennedy» (182). Es un tiempo excepcional en que el muchacho, dotado de una hipersensibilidad propia de la adolescencia, percibe el mundo -sonidos, olores, etc.- a través de sus sentidos. Hasta él llegan - «escucho y vigilo» (80)-, a través del balcón abierto y en medio de la «brisa lenta y cálida» (79), «el cielo azul marino de la noche de verano» (73), «el clamor lejano de grillos y de perros» (77), «el timbre débil de un teléfono» (78) de la casa del rincón en la que vive el ciego, que suena reiteradamente, los ruidos «de la última función del cine de verano» (79), «los murmullos de vecinos que aún no han dado fin a la tertulia nocturna, sentados en grupos junto a las puertas de las casas» (79), «el hilo de luz» desde «la ventana de la habitación» (83) donde agoniza Baltasar, «las campanadas del reloj de la sala» (85) que da las dos de la madrugada... En este capítulo sexto, en el amanecer del día 17 de julio, cuando toda la casa duerme, el protagonista sigue «despierto y asomado al balcón como un vigía en un faro» (84). El silencio de la plaza se ve alterado por el motor de un coche que luego se aleja, el timbre del teléfono, los pasos y golpes del bastón de Domingo González, el ciego, que regresa, y «un rumor de rezos» (85) por el moribundo.

Pero esa madrugada fuera de lo común tiene, además, una dimensión colectiva, política y social, en claro contrapunto simultáneo: alumbra el «Trigésimo tercer aniversario del Glorioso Alzamiento» (85-86), día grande en el franquismo, en ese «Primer año de la Era Espacial» (86), cargada de expectativas de progreso y novedades científicos.

En una de las frecuentes digresiones, esta vez sobre la subjetiva percepción del mundo a través de los sentidos, en ese mismo capítulo 6 , el vigilante protagonista no sólo es consciente de esto, sino también de la aparente quietud. En realidad, si se agudiza el poder sensitivo, tanto es factible captar el movimiento general como el suyo propio: «Nada está quieto, y menos que nada mi cabeza sin sosiego, excitada por el calor de la noche y por el insomnio, por las percepciones excesivamente agudas de los sentidos» (96).

Esta perspicacia sensitiva del adolescente se plasma en una prosa impresionista que proporciona raigambre lírica a la novela. Aparte de los mencionados más arriba, los ejemplos son numerosos: en el capítulo noveno, el muchacho percibe en la mañana «los trinos y aleteos de las golondrinas» (135), el «aroma espeso de la resina y de las flores de los álamos» (135), el ruido de las mujeres que «barren el empedrado y lo rocían luego con el agua sucia de los cubos de fregar» (137). En el capítulo séptimo, es el tacto, único sentido, el que aúna un conjunto áspero propio del mundo del protagonista: «las manos de los hombres, la pana de los pantalones de trabajo, los terrones secos, las paredes encaladas 
[...] la tela de los sacos [...] Los tallos y las hojas secas de las matas de garbanzos» (113). A todo ello se unen las manos de su padre que «tienen un tacto de madera serrada» (114). Sensaciones táctiles y olfativas provenientes de los frutos del campo es lo que llega al muchacho que ha tenido que madrugar el 18 de julio, día festivo, para acompañar a su progenitor en las tareas del huerto, casi al amanecer: «corre una brisa fresca y casi húmeda que levanta un rumor suave en las hojas de los árboles y trae consigo los olores limpios y precisos de la vegetación, de la tierra y del agua: el olor de las ovas en la alberca, el de las hojas ásperas y la savia picante de las higueras, el de las hojas tiernas y empinadas en el fresco del día de las matas de tomates» (180).

También, los diferentes colores: rojos, amarillos, verdes.., que junto a los distintos tamaños y texturas forman una auténtica sinfonía sensorial en la página $187^{15}$. En el capítulo décimo tercero, a partir de la caída de la tarde del domingo, 20 de julio, se produce un crescendo de sonidos y ruidos, previos al descubrimiento del cadáver del ciego: murciélagos y vencejos, voces de alarma, golpes de llamadores, la sirena de una ambulancia. A medianoche, los corros de vecinos hacen comentarios, que oye el protagonista, sobre el pasado del ahorcado, sus crímenes de guerra, sus tropelías con los vencidos, adhesión a la Falange, y su muerte, posible venganza. Más tarde, el silencio lo invade todo: «La casa entera es un gran depósito, un acuario de las aguas densas del sueño» (236). Percibe, entonces, en el unánime del espacio doméstico, «una polifonía de latidos» (237), tanto de los seres animados -los animales y las personas- como inanimados -el reloj-, en total simultaneidad entre todos ellos y con el astronauta Neil Armstrong.

La complejidad que el tratamiento temporal adquiere en la forma de la novela se subraya desde el punto de vista semántico. El tiempo subjetivo del protagonista no es el de su familia. El pasado de ésta, «lejano y sombrío» (82) tiene que ver con la guerra civil - un tema constante- y sus consecuencias, que el adolescente desconoce aunque atisba su carga opresiva: «yo no logro saber en qué consistió. No sé nada del pasado ni me importa mucho pero percibo su peso inmenso de plomo, la fuerza abrumadora de su gravedad» (82). Es un enigma que actúa de manera frustrante sobre la familia: «Lo que sucedió o no sucedió hace veinte o treinta años gravita sobre los mayores con una fuerza invisible que ellos mismos no advierten [...] No hay ningún adulto cuya figura no proyecte hacia atrás la sombra de lo que hizo o de lo que le sucedió en otro tiempo» (83).

15. Además las variadas sensaciones -sonoras, olorosas, gustativas- crean el espacio del cine de verano (195). Senabre (2006) en su reseña habla, en este sentido, de técnicas compositivas que recuerdan a Gabriel Miró. Véanse también las reseñas de Gracia (2006) y Pozuelo Yvancos (2006).

Anales, 21, 2009, pp. 117-141 
El muchacho sólo puede asomarse a ese trágico pasado a través de las «rendijas estrechas» (83) de lo poco que ellos cuentan porque no se atreven del todo a revivirlo. El acceso a los años de la guerra y de la inmediata posguerra se plantea en la novela con una fuerte dosis de suspense. Pero en esos días de julio se resuelve el misterio en torno no sólo a la familia, sino a los dos personajes clave del bando de los vencedores, Baltasar, ahora agonizante, y el ciego, ahorcado la noche del 18 de julio, del que el adolescente ha sido único testigo de su regreso a la casa en esa misma noche de viernes. Son todos ellos fundamentales descubrimientos autoformativos.

El abuelo, que había sido guardia de asalto al servicio de la República, es enviado a prisión mientras su mujer debe alimentar a cuatro hijos. Baltasar lo engaña con el dinero, ya sin valor en el régimen franquista, pero nunca busca la venganza, al contrario de la abuela. Los padres fueron niños de la guerra. La madre esperaba el regreso de su progenitor y adquiría responsabilidades de adulta cuidando de sus hermanos más pequeños. Precisamente, ese festivo 18 de julio, trabajando en la huerta, el protagonista conoce por boca de su padre, que tenía ocho años, los recuerdos sangrientos del alzamiento nacional y la dureza de su vida infantil. No regresó a la escuela después de la guerra porque le habría dado vergüenza, aunque el maestro asesinado por los vencedores le decía que valía para ingeniero agrónomo. La pasó haciendo labores agrícolas con su abuelo para sacar a la familia adelante, mientras su padre estaba en el frente. La contienda civil ha marcado, sin duda, su futuro: sólo el continuo e incansable esfuerzo le permitió comprar la finca en la que trabajaba, aunque apresado por las deudas. Además, las dificultades tras el conflicto han configurado la peculiar personalidad paterna, su conducta, su individualismo, su desconfianza asociativa: «Mira la gente en la guerra, todos apuntándose a los partidos y a los sindicatos, y en qué terminaron casi todos» (141).

Metafóricamente, la lentitud y la irrevocabilidad del tiempo vinculado a la victoria franquista y sus aniversarios se opone a la incitante rapidez del tiempo del viaje espacial, que tampoco es progresivo: «La duración de plomo del pasado se mide en conmemoraciones y en números romanos: a mí me gusta el tiempo inverso y la cuenta atrás que lleva segundo a segundo al despegue de un cohete Saturno, y más todavía el que empieza en el instante del despegue» (86). También con un sentido connotativo se enfrenta la dolorosa y traumática permanencia del tiempo de posguerra con la esperanzada y novedosa instantaneidad del tiempo del Apolo XI: su misión «no se mide por días ni por semanas, ni por largos años de repetición ceremonial del pasado, sino por horas, minutos, segundos» (83).

El factor tiempo, tan importante como en toda novela lírica, cuyo transcurso se señala continuamente en el relato primario con referencias cronológicas -días, 
horas, minutos, determinadas partes de cada jornada-, es concebido de diferente forma por el adolescente y por su familia. Para ésta, se define por la circularidad, es reiterada monotonía. Está marcado por el ritmo uniforme de la existencia y las cosechas, la campana de la iglesia o el reloj del pasillo, lo que le confiere un carácter ucrónico, de ausencia de sentido durativo. No hay novedades porque, para el protagonista, «el tiempo en el que viven no es una flecha lanzada en línea recta hacia el porvenir, sino un ciclo que se repite [...] Lo que a mí me aburre, me impacienta, me exaspera, a ellos les depara serenidad apacible» (109).

El espacio novelesco adquiere, asimismo, una relevante función en la novela lírica de aprendizaje. Ciertamente, puede establecerse una reciprocidad entre lo espacial y el protagonista, ya que, como consideró Ricardo Gullón (1980: 24), no sólo éste crea el espacio, sino que esa creación revela su carácter. Pero, además, como ha apuntado Rodríguez Fontela (1996a: 416), descubre también «la conciencia del proceso por el que el personaje adquiere tal carácter». Vuelve el autor de El viento de la Luna al mundo de Mágina, trasunto ficticio de su Úbeda natal, ya aparecido en novelas anteriores como Beatus Ille (1986) y El jinete polaco (1991), pero ahora conformado por la subjetividad de un adolescente que trasciende el simple topos. Se hace referencia a determinados subfocos espaciales con la mención de calles o plazas, se recrean ambientes como el del cine de verano o la tertulia nocturna de los vecinos y, claro está, se presta especial atención al colegio y a la casa familiar. Todo ello en fuerte contraste con ese otro mundo, ajeno y fascinador, del universo sideral.

La conformación del espacio, plasmado en una prosa medida y sugerente, adquiere un profundo carácter simbólico, propio de la novela lírica. Y esto desde el título que, como en otras novelas del género, obedece a una interpretación espacial bisémica (Rodríguez Fontela, 1996a: 419). El referente denotativo es, en principio, falso: «En la Luna no hay viento» (55) y por eso la «huella de cada paso que dan los astronautas [...] permanecerá indeleble durante millones de años» (55). El protagonista, que se ha identificado numerosas veces a lo largo de la novela con los héroes del viaje espacial, en el abierto final de ella, en otro tiempo de adulto y a través de lo onírico, recupera el espacio infantil y adolescente porque los recuerdos, como las pisadas en la superficie lunar, son imperecederos. El pasado, así, aparece también definitivamente recobrado. Y en esta revitalización es la figura ya muerta del padre la que proporciona, ahora sí, un asumido, melancólico, amoroso y mítico regreso a los orígenes.

Las dos novelas que han centrado nuestro trabajo, como otras que podrían estudiarse, pueden demostrar la pervivencia del viejo género de la autoformación en la literatura española de hoy en día. Y muy posiblemente, la causa de la salutífera presencia del bildungsroman en las letras actuales haya que encontrarla 
no sólo en su profunda significación humana, sino también en la memoria, para muchos triste, de la larga noche franquista.

\section{BIBLIOGRAFÍA}

BAJTÍN, Mijail (1982), «La novela de educación y su importancia en la historia del realismo», en Estética de la creación verbal, Madrid, Siglo XXI, pp. 200247.

CAMPBELL, Joseph (1980), El hombre de las mil caras, México, FCE, [1949].

FERNÁNDEZ VÁZQUEZ, José Santiago (2002), La novela de formación. Una aproximación a la ideología colonial europea desde la óptica del Bildungsroman clásico, Alcalá de Henares, Universidad.

FREEDMAN, Ralph (1972), La novela lírica. Herman Hesse, André Gide y Virginia Wolf, Barcelona, Barral, [1969].

GARCÍA-ABAD, M. ${ }^{a}$ Teresa (2005), «Fotogenia literaria en Carreteras secundarias, de Ignacio Martínez de Pisón: un viaje de ida y vuelta», Revista de Literatura, 67.133, pp. 95-118.

GRACIA, Jordi (2006), «Un adolescente en la Luna», Babelia, 2-IX-2006.

GUILLÉN, Claudio (2005), «Los géneros: genealogía», en Entre lo uno y lo diverso, Barcelona, Tusquets, pp. 137-171.

GULLÓN, Ricardo (1980), Espacio y novela, Barcelona, Antoni Bosch.

- (1984), La novela lírica, Madrid, Cátedra.

LUKCACS, Georg (1971), «Los años de aprendizaje de Wilhelm Meister, como tentativa de síntesis», en Teoría de la novela, Barcelona, Edhasa, [1920], pp. 143-155.

MARTÍNEZ DE PISÓN, Ignacio (1996), Carreteras secundarias, Barcelona, Anagrama.

MORETTI, Franco (1999), Il romanzo di formazione, Torino, Einaudi.

MUÑOZ MOLINA, Antonio (2006), El viento de la Luna, Barcelona, Seix Barral.

POZUELO YVANCOS, José M. ${ }^{a}$ (2006), «Muñoz Molina. La aventura del Apolo XI desde Mágina", ABC, 1-IX-2006.

RODRÍGUEZ FONTELA, M. a Ángeles (1996a), La novela de autoformación, Kassel, Univ. de Oviedo-Reichenberger.

- (1996b), Poética de la novela de autoformación. O Bildungsroman galego no contexto narrativo hispánico, Santiago de Compostela, Centro de Investigacións Lingüísticas e Literarias Ramón Piñeiro, Xunta de Galicia.

SALMERÓN, Miguel (2002), La novela de formación y peripecia, Boadilla del Monte, A. Machado Libros. 
SÁNCHEZ MAGRO, Andrés (1996), «Carreteras secundarias. Dos personajes en busca de destino», Reseña, 273, p. 34.

SENABRE, Ricardo (2006), Res. de El viento de la Luna, El Cultural, 14-IX-2006.

SHAFFNER, Randolph (1984), The Apprenticeship Novel. A Study of the Bildungsroman as a Regulative Type in Western Literature with a Focus on Three Classic Representatives by Goethe, Maugham, and Mann, Nueva York, Peter Lang.

VILLANUEVA, Darío (1984), Pról. a La novela lírica, I, Madrid, Taurus, pp. 9-23.

VILLEGAS, Juan (1973), La estructura mítica del héroe en la novela del siglo XX, Barcelona, Planeta.

Fecha de recepción: 14 de mayo de 2008

Fecha de aprobación: 1 de octubre de 2008 